\title{
SPERENCANAAN PENDEKATAN PERSUASIF DAN AKSI REMAJA PEDULI LIMBAH CAIR SEBELUM MASUK SUNGAI
}

\author{
Bernadeta Siti Rahayu Purwanti ${ }^{1)}$, Nuralam ${ }^{2}$, \\ Latif Mawardi $^{3)}$, Britantyo Wicaksono ${ }^{4)}$, Aulia Kahfi ${ }^{5)}$ \\ ${ }^{1}$ Elektronika Industri, Jurusan Teknik Elektro, Politeknik Negeri Jakarta \\ ${ }^{2,3,4}$ Jurusan Teknik Elektro, Politeknik Negeri Jakarta
}

\begin{abstract}
Abstrak
Artikel ini membahas rencana kegiatan Pengabdian Masyarakat (Pengmas) dengan skala prioritas, disesuaikan program/permasalahan desa. Program Desa Citeureup, Kabupaten Bogor, khususnya penanganan limbah cair di Blok Tempe. Area produksi menyatu dengan rumah tinggal. Pembuat/penjual tempe kejar target memenuhi pesanan pedagang/ pelanggan. Dari hasil suvey dan informasi aparat Desa, keuntungan pembuatan tempe sangat memadai/menunjang perekonomian warganya. Hanya saja limbah cair sisa produksi tempe tahu dibuang ke lantai. Saluran pembuangan ini menyatu dengan buangan air rumah tangga. Limbah di setiap saluran berujung ke badan air/sungai Cibeber. Pembuat tempepun sadar bahwa air limbah menimbulkan bau tak sedap, asap, dan menghitamkan dinding rumah/atap. Seolah limbah menyatu dengan kehidupannya, walaupun bahaya mengancam; penyakit, pencemaran air/udara, kematian biota air, hingga Gas Rumah Kaca (GRK). Solusi permasalahan limbah dengan pendekatan persuasif terhadap anak/Remaja Blok Tempe Bersatu BTB). Metodenya; pendampingan keterampilan, aksi penanganan limbah. Harapan ke depan para pengrajin tempe tergugah untuk meniru kegiatan anak-remaja. Aksi nyata mengolah limbah cair sebelum dibuang ke saluran drainase dengan dua set drum. Penyaringan limbah cair sirkulasi vartikal untuk aksi nyata remaja dan yang vertical untuk edukasi, simulasi real. Program pendampingan keterampilan terkait limbah cair dilaksanakan kontinu/berkesinambungan. Hasil pendampingan mengarah pada Blok Tempe Berseri. Jangka panjangnya menuju Central Industry and Destination Tourism.
\end{abstract}

Keywords: drum, limbah cair, sirkulasi, tempe, vertikal.

\begin{abstract}
This article discusses about community services with priority scale, it's been adjusted to rural problem in this case Citeureup Village Program Bogor district, especially tempe's waste water treatment. The production area merge with the house. Tempe artisan has a goal to fulfill the distributor's order. According to the survey and information from village officials, the profit from tempe is very supporting the economy of villagers. The problem is the production waste was thrown to the production floor and blends with household waste water. The waste from each channel goes to Cibeber river. Tempe artisan realized that the waste water cause odor, smoke, and blacken the roof. It seems like the waste already merge with their daily life, even though its dangerous; disease, air pollution, destruction of river ecosystem, and global warming. The solution of this problem is to persuade the youngster from Blok Tempe Bersatu (BTB). Method that we use is to assist the skill waste water treatment. We hope that in the future the tempe artisan is willing to mimic the BTB youngster. The real action on the field is to filter the waste water before it gets thrown away to drainage using two type of drum (vertical and horizontal type). The vertical type filtration circulation will be used on the field and the horizontal one will be used as real simulation education at class. Skill assistance program regarding waste water will be carried out continuously. The result of this program leads to series of Blok Tempe. The long-term output will be "Central Industry and Destination tourism".
\end{abstract}

Keywords: Drum, waste water, circulation, tempe, vertical

Correspondence author: Bernadeta Siti Rahayu Purwanti, rahayu.purwanti@elektro.pnj.ac.id, Indonesia 


\section{PENDAHULUAN}

Upaya penerapan teknologi tepat guna dan sarat manfaat oleh akademisis dangat diharapkan masyarakat. Sasaran utamanya menjadi sederhana atas permasalahan yang terkait dengan problem Teknik atau sosial humaniora. Bahkan gabungan keduanya, demikian halnya dengan permasalahan warga Blok Tempe, Citeureup. Solusi ditawarkan untuk masalahnya, dengan Teknologi Tepat Guna (TTG) dan metode pendekatan persuasif kepada warga pengrajin tempe. Tujuannya mengubah pola berfikir dan perilaku pengrajin tempe untuk peduli limba cairnya melalui aksi anak-remajanya. Hasil survey awal oleh tim Pengabdian Masyarakat pada hari Selasa, 2 April 2019 ke Blok Tempe Citeureup dsampaiakn sebagai data primer. Data berupa informasi warga, wawancara, dokumentasi/foto. Infrastruktur bangunan telah kokoh, habit warga sulit ditembus perubahannya. Permasalahan paling rumit dan tidak mendapat solusi adalah sikap para pembuat tempe, bersikeras tetap berproduksi tanpa gangguan". Sekecil apapun gangguan memicu emosi para pembuat tempe, termasuk perbaikan jalan/lorong. Perbaikan jalan tidak langsung mengganggu proses pembuatan tempe, mereka hanya tidak dapat lewat karena tehalang oleh program pembangunan desa. Para pembuat tempe tidak dapat diliburkan sehari sekalipun, walaupun demi kebaikan mereka. Para pembuat tempe suatu hari marah, akibat betonisasi tidak cepat kering. Mereka tidak bersedia memanggul tempe melewati jalan lain untuk distribusinya. Alasannya, perjalanan memutar dan membawa tempe berat, betonisasi dianggap menghalangi distribusi tempe.

Masalah besar lainnya adalah pembuangan limbah, terlanjur menyatu dengan semua air buangan rumah tangga. Saluran air/drainase tidak mungkin direvitalisasi. Maka tanpa daya dan buntu untuk mengajak mereka bekerjasama. Kerjasama dimaksud dalam upaya untuk menangani limbah cairnya. Ketika mereka diundang untuk musyawarah desa, terkait limbah selalu menuntut uang kompensasi, setidaknya transportasi. Sementara untuk ruang pertemuan desa cukup berberapa langkah dari rumahnya. Sementara itu, pembuangan limbah secara langsung semakin meningkat bersamaan dengan bertambahnya kapasitas produksi tempe/tahu. Aktifitas produksi mereka hanya libur 3-5 hari pada masa lebaran. Waktu yang sangat singkat dan tidak cukup untuk upaya apapun merevitalisasi Blok Tempe. Walaupun hanya sebagian kecil saja yang tetap produksi untuk melayani pesanan rumah makan. Hal tersebut menunjukkna bahwa para pembuat tempe hanya memikirkan produksi, tanpa mempedulikan efek dari limbahnya.

Besarnya pendapatan usaha dipengaruhi oleh faktor pendidikan, jumlah keluarga, jumlah tenaga kerja terhadap aspek sosial ekonomi.Aspek sosial ekonomi mempengaruhi pendapatan (Adya Hermawat. 2012) sesorang dalam usahanya. Banyaknya pengrajin di industri tempe/tahu berimplikasi pada tingginya pemerataan kesempatan usaha, Pemerataan kesempatan ini (Rohmansyah, 2017) sampai di tingkat industri kecil skala rumah tangga (home industry). Peran pendapatan usaha tempe cukup penting dan mempengaruhi pengembangan perekonomian desa. Pembuatan tempe/tahu membuka peluang usaha, penyerapan tenaga kerja, pemerataan pendapatan, pemenuhan protein, dan perbaikan status gizi masyarakat. Upaya penanggulangan pencemaran lingkungan oleh masyarakat dengan mengolah limbah industri. Hal ini meminimalisasi biaya pengolahan limbah dan menambah pendapatan atau penghasilan (Iftitah, Yekti, \& Suryaningsih, 2017).

Dampak negatif usaha tempe/tahu, semakin banyak limbah dan pencemaran lingkungan. Tantangan berat bagi masyarakat ilmiah, adalah bagaimana pemerintah menyikapi nasib generasi penerus anak bangsa akibat cemaran/limbah. Limbah industri 
tempe/tahu menimbulkan berbagai masalah jika tanpa penanganan. Limbah merupakan sumber polutan, bila tidak ditangani berdampak pada peningkatan penyakit kulit dan pernafasan. Gatal-gatal dari air mandi akibat pencemaran, sesak nafas akibat menurunnya kadar oksigen di udara. Sisa-sisa bahan kimia pengolahan dan pembersihan, air buangan (efluen) juga berbahaya. Kandungan Biological Oxygen Demand (BOD) limbah buangan pembuatan tempe/tahu cukup tinggi (Lusiana, Puryantoro. 2018). Selain itu juga mengandung polutan seperti tanah, larutan alkohol, panas dan insektisida. Akibat pembuangan lansung efluen ke perairan adalah terganggunya seluruh keseimbangan ekologik, menyebabkan kematian ikan dan biota air lainnya. Sementara itu, pemerintah telah membatasi baku mutu limbah cair industry. Batas baku mutu limbah industry tempe/tahu; BOD maksimal 75 mg/l, COD maksimal 200 mg/l, TSS maksimal 50 mg/l, dan $\mathrm{pH}$ anatara 6-9.

Metode penanganan limbah telah direalisasikan, salah satunya dengan pemanfatan tanaman eceng gondok. Tanaman ini dapat mengurangi bahan organik air buangan sebagai persisten, sumber utama pengelolaan limbah dan proses pertanian. Penanggulangan limbah dengan memanfaatkan tanaman penyerap Thypa Latifolia (D.A. Disyamto, S. Elystia and I. Andesgur. 2014), eceng gondok (A. I. Alfarokhi. 2016) untuk limbah tahu. Kedua peneliti berupaya meminimalisasi pencemaran limbah sektor industri tempe/tahu yang berpengaruh besar terhadap kelestarian lingkungan. Oleh karena itu peduli lingkungan harus diupayakan semaksimal mungkin oleh masyarakat. Walaupun upaya tersebut tidak mudah, perlu perjuangan berat tetapi bukan sesuatu yang mustahil. Harapannya para pelaku industri mulai memperbaiki perilaku dan membenahi cara pembuangan limbahnya.

Seperti halnya permasalahan di Blok Tempe ini, harus disiasati untuk merintis perubahan habit dan kesadaran warganya terkait pembuangan limbah. Salah satu peluangnya dengan menanamkan wawasan dan aksi nyata tentang hubungan limbah dan masa depan generasi muda. Regenerasi disiapkan sedini mungkin agar tidak mengikuti habit orang tuanya yang stidak peduli lingkungan. Keterlibatan anak-anak dan remaja Blok Tempe dalam melaksanakan kegiatan pengolahan limbah perlu digalakkan. Program Pengabdian Masyarakat PNJ direncanakan dengan melaksanakan kegiatan keterampilan pengolahan limbah cair. Kegiatnnya dalam bentuk edukasi dan aksi nyata mengolah limbah cair sisa produksi tempe/tahu. Peserta edukasi dan aksi nyata adalah anak dan remaja Blok Tempe. Bentuk edukasinya dengan pemutaran film dan praktik menjernihkan limbah hingga layak buang. Film tentang pembuatan tempe yang bersih dan pembuangan limbahnya telah sesuai standar pengolahannya. Pertimbangan pemilihan kedua kegiatan ini, sebagai solusi/alternative sulitnya menembut habit pembuat tempe. Anak dan remaja masih mudah diberi pemahaman baru dan modern karena tidak terikat dengan produksi tempe. Hal lainnya, tercipta pola pikir tentang pentingnya pengolahan limbah sejak seddini mungkin. Perubahan perilaku anak dan remaja untuk peduli limbah diharapkan berpengaruh terhadap perilaku orang tuanya. Setidaknya melalui sikap dan berbagai aksi peduli limbah oleh anak-anak/remaja, maka para orang tuanya terpanggil untuk meniru.

\section{METODE PELAKSANAAN}

Studi Literatur terkait dengan limbah cair dan survey ke Blok Tempe ditemukan sikap warganya terhadap penanganan penanganan limbah. Permasalahan yang telah terhimpun diupayakan solusinya agar metode penyelesaiannya tepat sasaran. Teknik 
Pendekatan Persuasif dipilih untuk mengubah pola berfikir dan sikap para pengrajin tempe. Waktu pelaksanaan dijadwalakn 16 minggu mulai minggu ke-2 bulan Mei 2019. Adapun Kerangka Berfikir Pengmas (Gambar 1) disesuaikan dengan hasil identifikasi permasalahn melalui survey ke Blok Tempe, Citerureup.

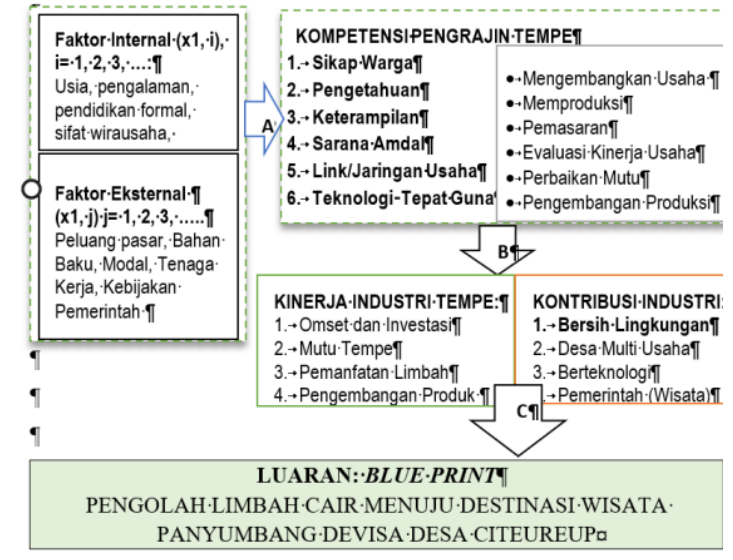

Gambar 1 Kerangka Perfikir Pengmas

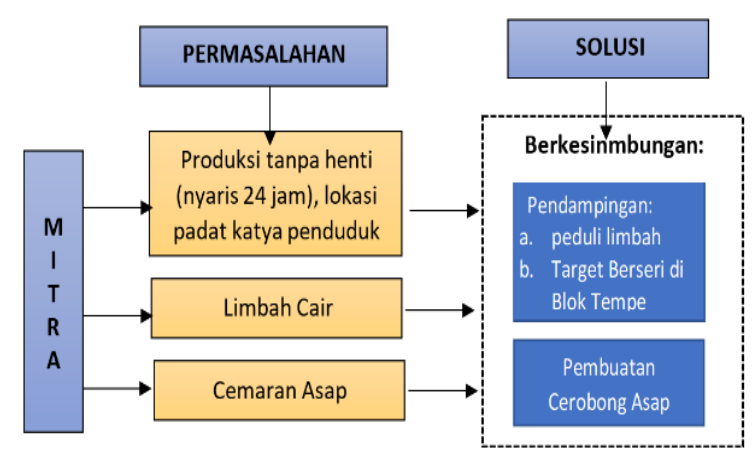

Gambar 2 Fokus Kegiatan Pengabdian Masyarakat Tahun 2019

Saat survey 2 April 2019, Masih ditemukan ketidaklayakan air buangan industri di Blok Tempe. Air di sungai keruh berbusa, walaupun tidak berbau menyengat karena air cukup deras (musim penghujan, ketika survey). Tidak dijumpai peluang berkolaborasi dengan para pembuat tempe, konsep kental time is money bagi mereka sangat kental. Celah kemitraan adalah anak dan remaja, kegiatan inovasi dan kreasi mereka memungkinkan untuk dilaksanakan kerjasama. Remaja Blok Tempe Bersatu telah memulai kegiatannya pengelolaan sampah tergabung dalam Bank Sampah. Klaim salah satu aparat Desa mendapatkan tunjangan Hari Raya dari Bank Sampah. Media capaian sasaran utama adalah melalui aksi nyata anak dan remaja untuk berkontribusi pada pengolahan limbah cair. Berbagai masalah inilah yang mendasari rencana kegiatan berkesinambungan dan berkelanjutan di Desa Citeureup.

Salah satu solusi jangka pendeknya dengan aksi nyata penanganan limbah cairr sisa produksi tempe tahu. Hal ini sesuai dengan informasi Ibu Evi, sekretaris Desa Citeureup, urgensi program Desa adalah pengolahan limbah. Air dari seluruh tahapan proses pembuatan tempe/tahu mengalir ke sungai, dan limbah padat sisa pengemas bahan daun teronggok sebagai sampah. Besaran baku mutu limbah cair yang masuk ke sungai belum terukur. Khususnya limbah cair belum ditangani sebagai prioritas agar air sungai lebih jernih dan tidak bau. Prioritas program Desa direspon cepat oleh Tim Pengmas dengan membuat alat berupa untuk meminimalisasi kadar limbah cair tempe/tahu. Tahap awal Pengmas mengutamakan skala prioritas (Gambar 2) dengan Penanganan Limbah Cair sesuai urgensi Program Desa.

Pelaku aksi penanganan limbah adalah anak- remaja yang tergabung dalam kelompok Blok Tempe Bersatu (BTB). Pendekatan persuasif Tim Pengmas sangat berharap kepada anak dan BTB ini untuk menularkan keterampilannya kepada orang tua masing-masing dan para pengrajin tempe. Kegiatan mereka dalam dalam Pengmas dengan mengikuti sosialisasi, pendampingan keterampilan penggunaan alat pengolah limbah cair. Aksi nyata anak-remaja BRB ini dapat mengetuk pintu hati setiap pengrajin yang telah melihat bukti nyata perubahan kejernihan limbah cair tempe/tahu. Sampel limbah diambil dari beberapa pengrajin, dimulai dari yang orang tua dari anak-remaja BTB. 
Limbah cair tempe/tahu telah diolah menjadi pupuk organik (Lusiana, Puryantoro. 2017), juga membuatankan asap cerobong. Kepulan asap sekitar industri tempe/tahu telah tertangani dengan dibuatnya cerobong asap. Metodenya dengan pendampingan berkesinambungan sehingga tercapai target dari solusi yang ditawarkan. Hasil pengabdian masyarakat; pupuk organik limbah cair telah mejadi usaha sampingan dan produk unggulan desa.

\section{HASIL DAN PEMBAHASAN}

Sesuai dengan prioritas permasalahan dan hasil survey direncanakan Program Pengmas (Gambar 3). Target kegiatannya meminimalisasi limbah cair sebelum dibuang ke badan air sungai Cibeber. Rencana tersebut juga sejalan dengan fokus kajian Indonesia Sanitation Sector Development Program (ISSDP) pada masalah sanitasi. Sanitasi di Indonesia masih pada tingkatan supply driven, pengembangan sanitasi menjadi hak penuh demand driven belum demand responsive. Desain sanitasi dimanfaatkan kontinyu dan berkelanjutan (sustainability). Pergeseran dari supply driven ke demand driven (Bappenas, 2006) tujuan pemanfaatannya berubah. Awalnya masyarakat mempunyai jamban (yang merupakan supply driven), dekade berikutnya berubah penekanan pada sarana. Inisiatif memilih sarana dan prasarana (demand driven) untuk pengelolaan air limbah domestik (Bappenas, 2006). Pergeseran fungsi dan fokus pemanfatan sanitasi ini berkaitan dengan penanganan limbah. Setiap rumah tangga, industri diwajibkan menangani limbahnya sebelum masuk ke badan akiran air.

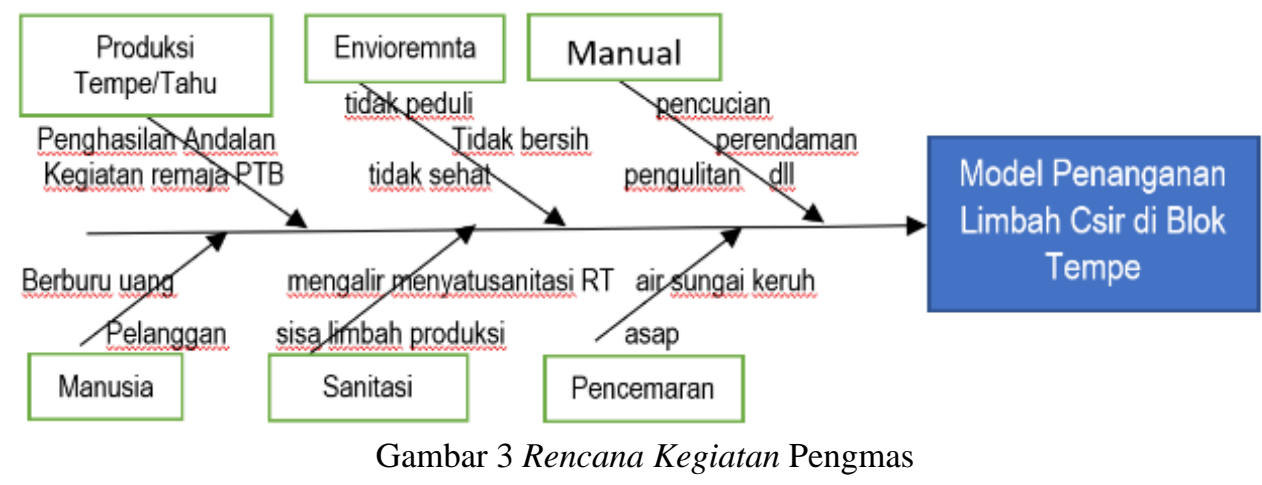

Keterampilan penanganan limbah cair di Blok Tempe mustahil difikirkan oleh para pembuat produk yang belum/tidak peduli lingkungan. Habit time is money tanpa kompromi dan anti gangguan sekecil apapun berdampak pada terganggunya kelestarian lingkungan. Gangguan lingkungan ditandai dengan menurunnya kualitas air, tercemarnya udara yang dideerita/ditanggung oleh genereasi penerus usahanya. Oleh karena itu anak dan remaja perlu dibekali keterampilan untuk penanggulanagan limbah indutri usaha orang tuanya. Anak dan remaja ini masih memungkinkan untuk diajak berfikir dan bertindak dengan aksi mengantisipasi kerusakan lingkungan. Rencana pelaksanaan Pengmas (Gambar 4) dapat berubah mengikuti stuasi dan kondisi kegiatan dengan tetap merujuk pada target dan luarannya. 


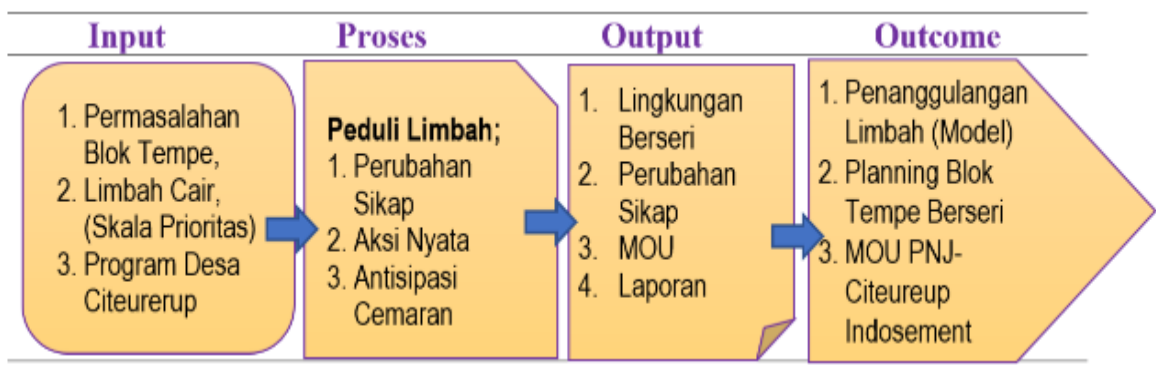

Gambar 4 Blok Prose Output dan Outcome Jangka Panjang Pengmas.

Output (luaran) setiap sub kegiatan disiapkan untuk mencapai outcome dan mengarah pada imbas perubahan perilaku terhadap kebersihan dan keindahan lingkungan Blok Tempe.

1. Planning menuju Blok Tempe Bersih Sehat Indah (Berseri), ditandai dengan tidak lagi dijumpai sampah di lantai rumah, pembuangan limbah cair di-treatmen sebelum masuk ke saluran air/selokan, penghijaian di sekitar Kantor Desa dan area yang memungkinkan di lorong Blok Tempe.

2. Model penanggulangan limbah dengan pengendapan dan filterisasi di dalam drum terealisasi ( $\pm 50 \%$ pengguna model). Layak MoU dengan industri

3. Keterampilan Remaja untuk Pengukuran Limbah di Blok Tempe;

a. COD, BOD, dan TTS, suhu, dan $\mathrm{pH}$ sebelum pendampingan

b. COD, BOD, dan TTS, suhu, dan $\mathrm{pH}$ menggunakan model penjernihan sebagai pendampingan

c. Hasil pengukuran sesudah pendampingan dibandingkan dengan standar mutu limbah sesuai ketentuan pemerintah.

d. Data hasil pengukuran dibandingkan untuk cemaran limbah sebelum dan sesudah masuk sungai

4. Target Pendampingan Keterampilan

Anak dan remaja dapat menggunakan alat ukur, menghitung angka cemaran dengan aplikasi, menggunakan aplikasi. Praktik menangani limbah cair produksi tempe/tahu melalui model (edukasi). Secara bertahap melibatkan orang tua mereka untuk menangani limbah masing-masing melalui proses penyaringan. Aksi nyata minimalisasi buangan air limbah ke sungai sesuai batas/standar baku nilai/angka Chemical Oxygen Demand (COD), Biomedical Oxygen Demand (BOD), dan Total Suspended Solid (TTS). Berkurangnya limbah di sungai sebagai upaya mewujudkan program GRK dari cemaran produksi industri tempe.

Tahapan Rencana Pengmas Rencana jangka menengah/Panjang (Gambar 6), menjadi acuan penyusunan target, luaran jangka menegah/panjang disajikan dalam Roadmap (Gambar 7).

1. Terbangunnya sentra-sentra dengan indutri hasil olahan tempe dan pengembangan pruduk unggulan masyarakat, antara lain:

a. Kelompok Remaja Bisnis limbah secara online olahan tempe,

b. Inovasi Remaja BTP terarah; penanganan limbah, pelaksanaannya terprogram rutin dan berkesinambungan

c. Kelompok Anak

d. Komunitas Warga Blok Peduli Limbah Pengguna Model Pengolahan Limbah Vertikal 
e. Kelompok Usaha Pupuk Limbah

f. Kelompok Edukasi dan Informasi Pengolahan Limbah

2. Roadmap Pengmas

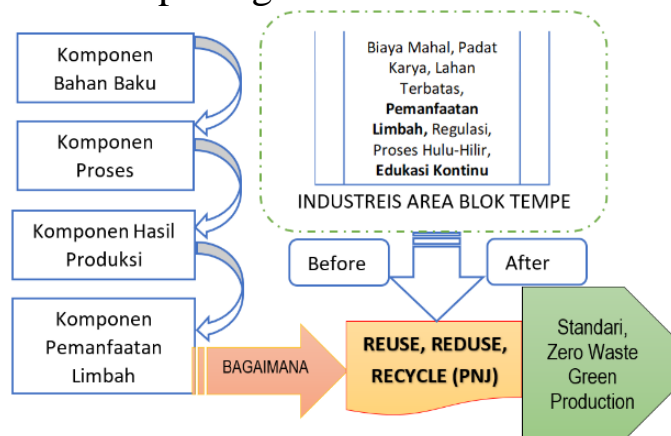

Gambar 6 Pengmas Jangka Panjang

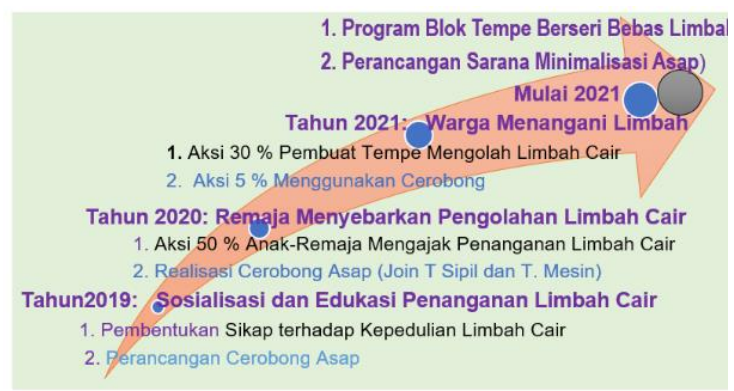

Gambar 7 Roadmap Kegiatan Pengabdian Masyarakat

Base Line:

a. Simulasi Desain Model Penyaringan limbah sisa produksi tempe/tahu (Silvi Wahyu Puspawati. 2014), Prosiding Sem.Tek. Pengolahan Limbah.

b. IbM Penangan Limbah Kantin (Purwanti. 2016), Prosiding Senaspro 2016.

3. Lokasi Blok Tempe (Gambar 8).

a. Jarak dari PNJ ke Blok Tempe 27 $\mathrm{km}$, dua titik rawan maceet yaitu di pintu exit Citeureup tol Jagorawi dan persimpangan Jalan Mayor Oking

b. Jika kedua jalan ini lancer maka waktu tempuh dari PNJ ke Blok Tempe \pm 35 menit

c. Peta Lokasi Blok Tempe, Citeureup, Kabupaten Bogor (Google Map. 2019)

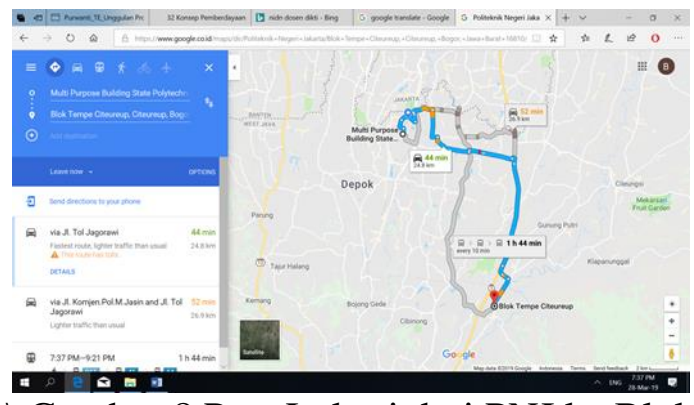

\Gambar 8 Peta Lokasi dari PNJ ke Blok Tempe

Dokumentasi hasil survey yang menjadi bukti belum pedulinya para pembuat tempe warga di Blok Tempe. Gambar 9, tempat peniris berupa rak kayu/bamboo terlihat berjajar slorong jalan Blok Tempe (kiri) dan aktifitas pembuat tahu (kanan). Gambar 10, memperlihatkan berbagai peralatan pembuatan tempe di area padat/sempit. Keterbatasan area tidak menyurutkan produksi, hanya saja dari sisi K3 belum memadai. Gambar 11, pembuangan limbah cair tanpa proses berpotensi pencemaran lingkungan dan badan air sungai Cibeber. 
Perencanaan Pendekatan Persuasif dan Aksi Remaja Peduli Limbah Cair sebelum Masuk Sungai (Bernadeta Siti Rahayu Purwanti, Nuralam, Latif Mawardi, Britantyo Wicaksono, Aulia Kahfi)|201
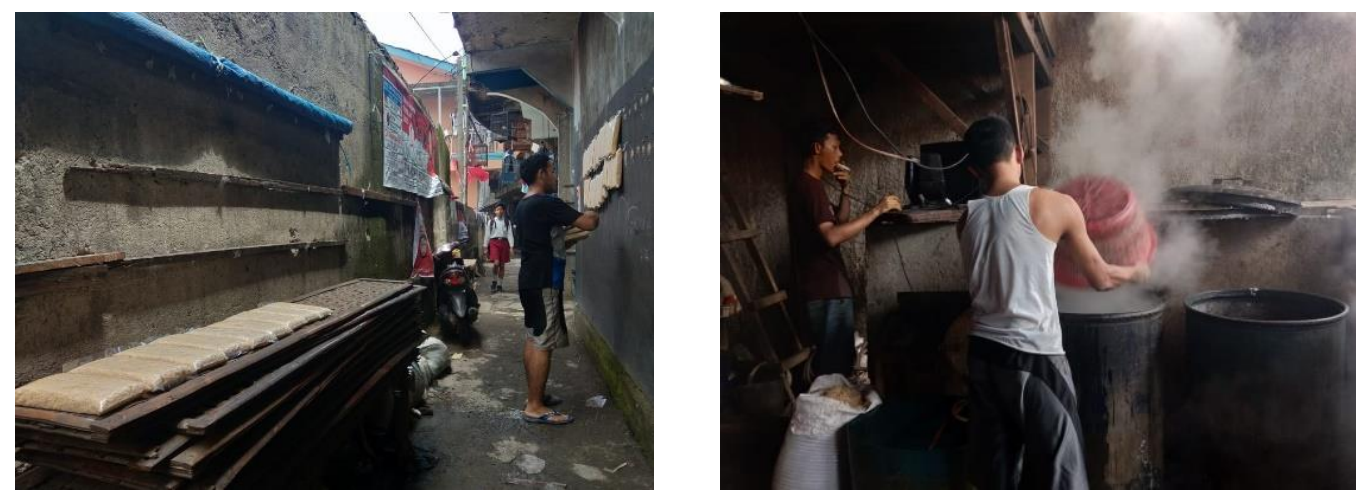

Gambar 9 Aktivitas Pengrajin di Lorong dan Berdempetan Jalan Blok Tempe
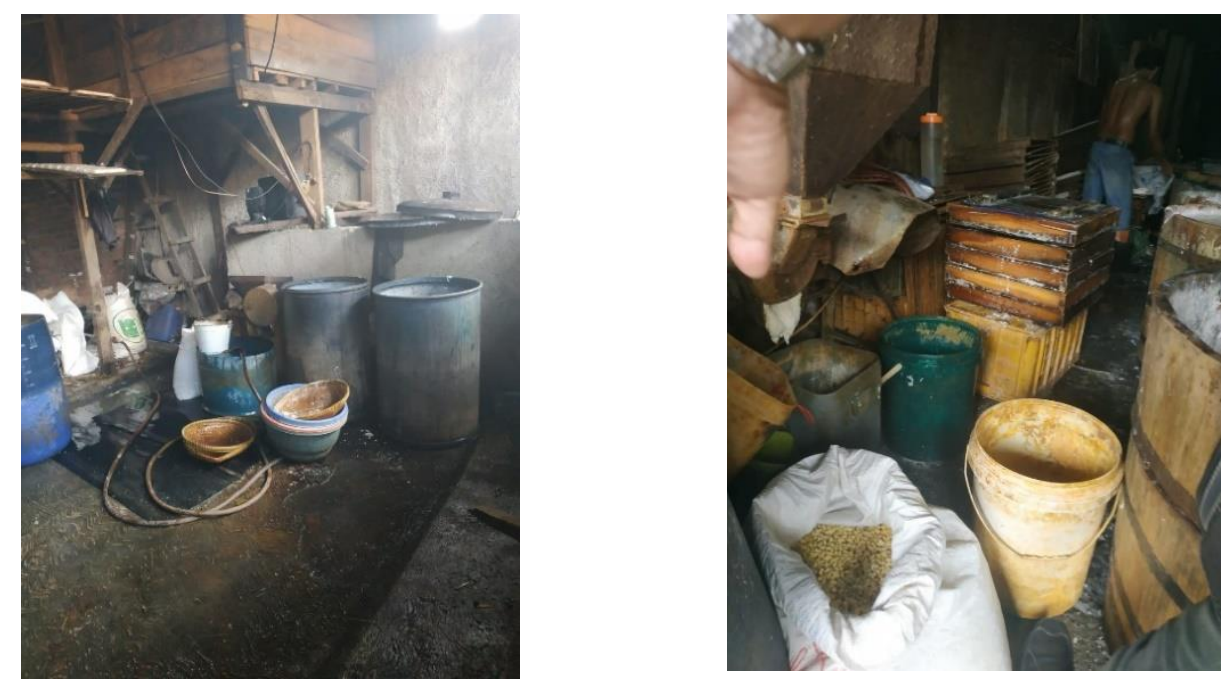

Gambar 10 Peralatan Pembuatan Tempe (kiri) dan Tahu (kanan)
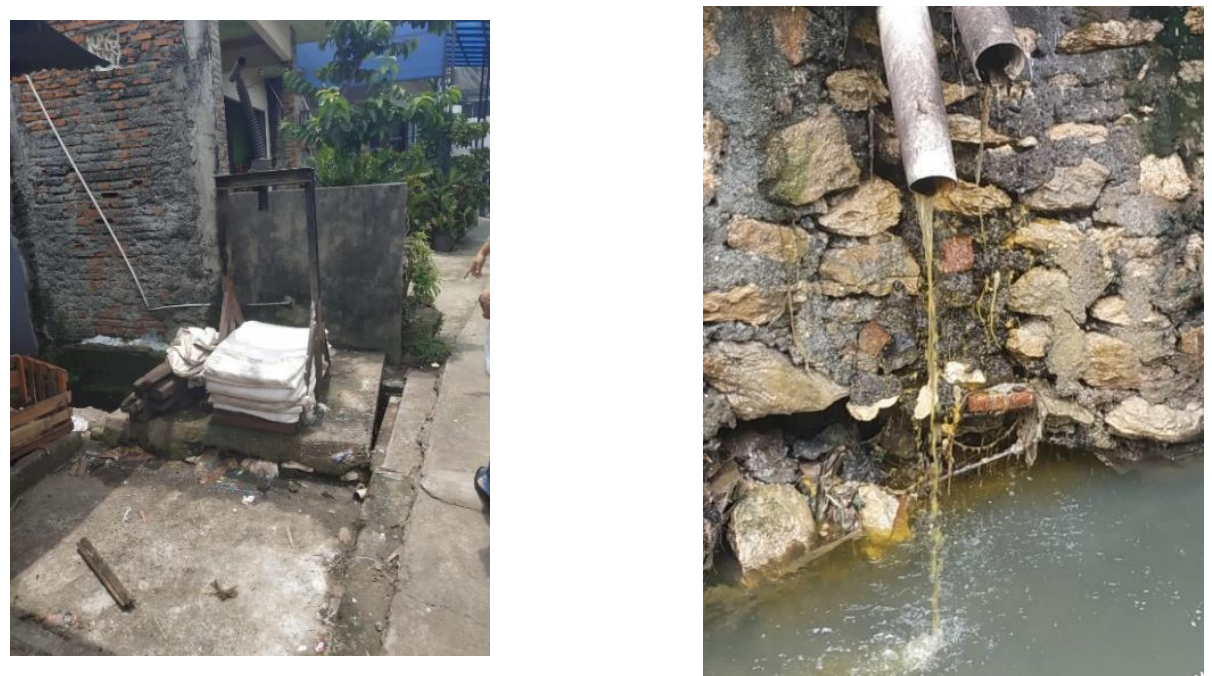

Gambar 11 Pengepresan Limbah Tahu (kiri) dan Air dari Saluran Blok Tempe (kanan) Masuk ke Sungai Cibeber 
Harapan pasca sosialisasi dengan aksi penanganan limbah merubah perilaku para pembuat tempe sesuai tahapan, yaitu:

1. Anak-anak Blok Tempe

Wawasan, pemahaman terhadap limbah cair produksi tempe/tahu berimbas pada perubahan perilaku. Aksi nyata berperilaku peduli limbah dengan mempraktikkan pengolahan air limbah menjadi lebih jernih pada "Media Edukasi Pengolahan Limbah Cair Vertical".

2. Remaja BTB

Perubahan perilaku organisasi Remaja BTB menuju orientasi bisnis terkair pengolahan limbah cair. Aksi nyata berperilaku peduli limbah dengan mengplah air limbah. Sasaran air limbah orang tuanya, beberapa warga dengan melaksanakan kegiatan "Pengolahan Limbah Cair Media Vertikal". Lokasi dipilih berdasarkan pertimbangan teknis, social, dan prospek bisnis, serta sikap peduli yang dinilai dari kontribusi warga. Kontribusi dimaksud bukan dinilai dari uang, tetapi karakter dan perilaku.

3. Harapan Perubahan Perilaku Pembuat Tempe Orang tua dari Anak dan Remaja diharapkan dapat meniru seyelah menerima pemahaman dari aksi anak-remaja dalam aksi pengolahan limbah, keterbukaan pikiran tentang bahaya produksi tempe berpotensi merusak alam/ lingkungan.

4. Desain Pengolah Limbah Cair (Gambar 13) Model Horisontal (kiri), dan Vertikal (kanan).

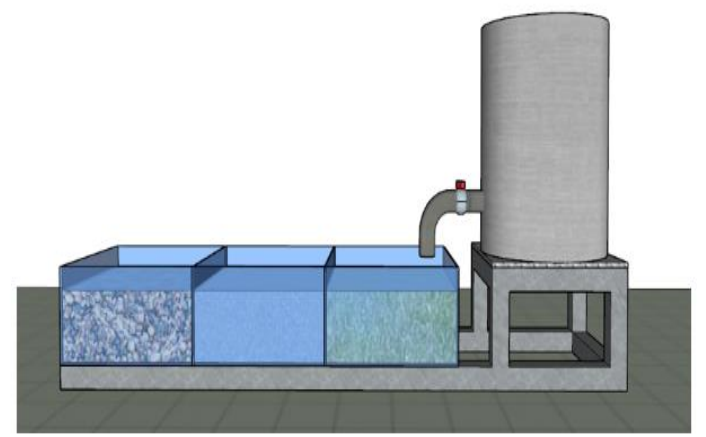

Gambar 9 Desain Model Pengolahan Limbah Horisontal

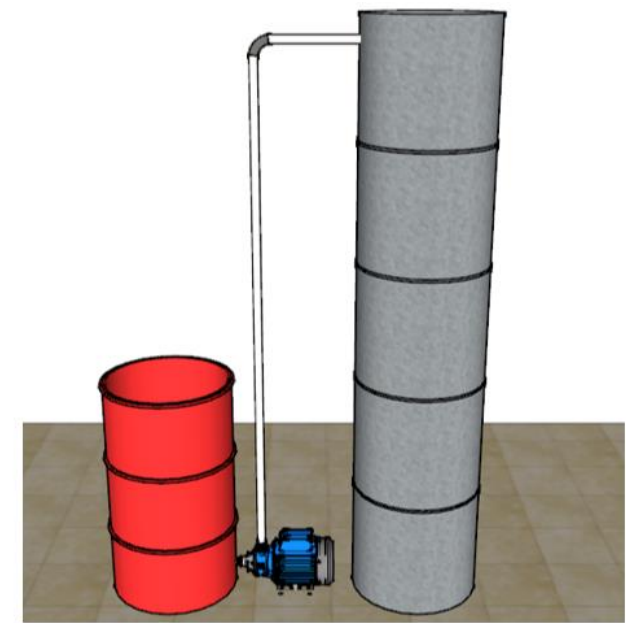

Gambar 10 Desain Model Pengolahan Limbah Vertikal

5. Dimensi ModelModel Horizontal ( $\mathrm{p} \times 1 \times \mathrm{t}: 170 \times 40 \times 80) \mathrm{cm}$, bahan tandon limbah adalah drum dengan aliran vertical (Gambar 9). Model ini menjadi media transfer keterampilan untuk anak-anak, sebagai aksi nyata pemahaman penanganan limbah cair industri tempe/tahu. Konsep perpindahan air antar ruang filter mengandalkan konsep beda ketinggian aliran. Model Vertikal (t x diameter x lebar: 170 x 40 x 80) $\mathrm{cm}$. penjernihan ke-1 m, limbah masuk ke drum yang melewati penampung dan penyaring serat. Sementara lima drum lainnya disusun untuk penjernihan tahap ke-2. Pengolahan sirkulasi limbah model vertical (Gambar 10) mengandalkan gaya grafitasi pada kedua set drum. Pemindahan dari set drum ke-1 ke set drum ke-2 menggunakan motor pompa. 


\section{SIMPULAN}

Perilaku para pengrajin tempe dan tahu masih belum/tidak peduli limbah, budaya Berburu Uang. Aparat Desa tidak sanggup mengalihkan pola berfikir keterkaitan bahaya limbah dan sisa produksi tempe/tahu. Mereka juga mengeluh pada tabiat para warganya karena harus memberi uang transport sebagai kempensasi bila diundang ke desa. Sikap dan tabiat para pembuat tempe ini menunjukkan belum/tidak munculnya peduli limbah. Perilaku masyarakat ini cukup unik, uang/rejeki mereka peroleh dengan usaha di Blok Tempe tetapi rasa memilikinya areanya belum terbangun. Lebih diperkuat lagi dengan perilaku pembuangan limbah cair ke lantai area produksi dan mengalir ke selokan saluran pembuangan rumah tangga. Oleh karena itu rencana pendekatan persuasif ke anak dan remaja sudah saatnya direalisasi. Minimal anak dan remaja dapat mempengaruhi atau mengubah sikap dan perilaku orang tuanya/pembuat tempe melalui aksi nyata pengolahan limbah.

\section{DAFTAR PUSTAKA}

Hermawati, A. (2012). Peranan aspek sosial ekonomi perajin tempe terhadap pendapatan dan partisipasinya sebagai anggota primkopti. Jurnal Sains Manajemen. ISSN. $1(1)$,

Alfarokhi, A. I. (2016). Pemanfaatan Eceng Gondok (Eichhornia Crassipes) Sebagai Tumbuhan Fitoremediasi Dalam Proses Pengolahan Limbah Tambak Udang Vannamei (Doctoral dissertation, UII Yogyakarta)..

Bappenas, (2006). Indonesia Sanitation Sector Development Program Inception Report (Volume 2) Annex 130.

Disyamto, D. A., Elystia, S., \& Andesgur, I. (2014). Pengolahan Limbah Cair Industri Tahu Menggunakan Tanaman Thypa Latifolia dengan Proses Fitoremediasi. Jurnal Online Mahasiswa Fakultas Teknik Universitas Riau, 1(2), $1-11$.

Iftitah, G., Yekti, A., \& Suryaningsih, Y. (2017). Pelatihan Pembuatan Cookies dari Ampas Tahu bagi Masyarakat Kelurahan Ardirejo sebagai Upaya Pemanfaatan Limbah Padat Pembuatan Tahu. Jurnal Paradharma 1, 1(April 2017), 28-34.

Lusiana, P. (2018). Penanggulangan Pencemaran Lingkungan Melalui Pkm Ukm Tahu Dan Tempe Dengan Pemanfaatan Limbah Industri ISSN 2622-3813 (online) ISSN 2614-7912 (cetak) Vol. 1, No. 2, Jul 2018, hlm 01-94, http://jurnal.stmikroyal.ac.id/index.php.s

Purwanti, R., \& Rebet, I. (2016). Pengukuran Suhu Ruang Pengompos Biopori Berbahan Baku Limbah/Sisa Makanan. Prosiding Seminar Nasional Gelar Produk, 17-18 Oktober 2016. Kampus UM Malang, hlm.364-371.

Rohmansyah, N. A., Nurdyansyah, F., \& Prastiwi, B. K. (2017). Pemberdayaan Masyarakat Melalui IbM Pelatihan Olahan Limbah Tahu Di Desa Drono Ngawen Klaten. Jurnal Kewirausahaan dan Bisnis, 21(11). hlm.42-48 
Puspawati, S.W. (2017). Alternatif Pengolahan Limbah Industri Tempe dengan Kombinasi Metode Filtrasi dan Fitoremediasi. Prosiding Seminar Nasional Teknologi Pengelolaan Limbah XV - 2017, hlm.129-136. SSN 1410 - 6086. 